\title{
Biological effects of inorganic arsenic on primary cultures of rat astrocytes
}

\author{
IRENE CATANZARO $^{1 *}$, GABRIELLA SCHIERA ${ }^{2 *}$, GIULIA SCIANDRELLO $^{1}$, GIUSI BARBATA $^{1}$, \\ FABIO CARADONNA ${ }^{1}$, PATRIZIA PROIA ${ }^{3}$ and ITALIA DI LIEGRO ${ }^{2}$ \\ ${ }^{1}$ Dipartimento di Biologia Cellulare e dello Sviluppo, ${ }^{2}$ Dipartimento di Biomedicina Sperimentale e Neuroscienze \\ Cliniche; ${ }^{3}$ Dipartimento di Studi Giuridici, Economici, Biomedici, Psicosociopedagogici delle \\ Scienze Motorie e Sportive, Università degli Studi di Palermo, Palermo, Italy
}

Received June 29, 2010; Accepted July 26, 2010

\section{DOI: 10.3892/ijmm_00000485}

\begin{abstract}
It is well established that inorganic arsenic induces neurotoxic effects and neurological defects in humans and laboratory animals. The cellular and molecular mechanisms of its actions, however, remain elusive. Herein we report the effects of arsenite $\left(\mathrm{NaAsO}_{2}\right)$ on primary cultures of rat astrocytes. Cells underwent induction of heat shock protein 70 only at the highest doses of inorganic arsenic (30 and $60 \mu \mathrm{M}$ ), suggesting a high threshold to respond to stress. We also investigated arsenic genotoxicity with the comet assay. Interestingly, although cells treated with $10 \mu \mathrm{M}$ arsenite for $24 \mathrm{~h}$ maintained $>70 \%$ viability, with respect to untreated cells, high DNA damage was already observed. Since arsenic is not known to be a direct-acting genotoxic agent, we investigated the possibility that its effects are due, in astrocytes as well, to ROS formation, as already described for other cell types. However, FACS analysis after $\mathrm{CM}-\mathrm{H}_{2}$ DCFDA staining did not evidence any significant increase of ROS production while, on the contrary, at the highest arsenite concentrations used, ROS production decreased. Concordantly, we found that, if most cells in the culture are still alive (i.e. up to $10 \mu \mathrm{M}$ arsenite), they show a treatment-dependent increase in the concentration of SOD1. On the other hand, SOD2 concentration did not change. Finally, we found that astrocytes also synthesize PIPPin, an RNA-binding protein, the concentration of which was recently reported to change in response to stress induced by cadmium. Here we also report that, in cells exposed to high doses of arsenite, an anti-PIPPin antibody-positive faster migrating protein appears.
\end{abstract}

Correspondence to: Professor Italia Di Liegro, Dipartimento di Biomedicina Sperimentale e Neuroscienze Cliniche, Sezione di Scienze Biochimiche, Via del Vespro 129, I-90127 Palermo, Italy E-mail: diliegro@unipa.it

${ }^{*}$ Contributed equally

Key words: inorganic arsenic, astrocytes, cell damage, DNA damage, PIPPin

\section{Introduction}

Arsenic is a well known toxic metalloid, widely distributed in nature. It is released into the environment through industrial processes and agricultural usage. Human exposure therefore mainly occurs by consumption of water and food $(1,2)$. Arsenic has been classified as a potent environmental carcinogen for humans (3), inducing a variety of malignancies, especially skin and lung cancers (4). Moreover, arsenic exposure gives rise to cardiovascular diseases and neurological dysfunctions (5).

Although intensively studied, it is not well understood how arsenic acts in living cells, but important insights into the mechanisms that promote arsenic-induced carcinogenesis have been provided by investigations on cultured cells exposed to acute or chronic arsenic treatment. Effects observed just after treatment are aneuploidy and DNA methylation alterations (6). These findings are consistent with a non-mutagenic mode of action and are suggestive of indirect genotoxic mechanisms (7).

Important targets of arsenic appear to be the mitochondria where production of reactive oxygen species (ROS) induces dissipation of mitochondrial transmembrane potential, leading to apoptosis $(8,9)$. In addition, arsenic activates an endoplasmic reticulum (ER) stress-mediated pathway of cell apoptosis (10). These effects could be related with modulations of $\mathrm{Ca}^{2+}$ induced signaling, as recently demonstrated by Florea et al (11). Micromolar concentrations of arsenic triggered an increase of intracellular $\left[\mathrm{Ca}^{2+}\right]$, inhibited cell growth and induced apoptosis in malignant cell lines (12).

Since it has been reported that nonlethal exposure to arsenic induces neurotoxic effects and neurological diseases in humans and laboratory animals (13-16), it is worth studying how arsenic acts on brain cells. The present study was aimed at analyzing the effects of $\mathrm{NaAsO}_{2}$ on primary cultures of rat astrocytes by determining DNA damage by comet assay, and evaluating possible changes of the concentration of the highly conserved heat shock protein 70 (Hsp70) and its housekeeping counterpart, Hsc70. We also investigated the effects of arsenic on PIPPin (also called CSD-C2), a putative RNA-binding protein expressed in the brain and probably involved in the post-transcriptional regulation of genes encoding replacement histones, and in the terminal differentiation of different classes of brain cells (17-19). PIPPin shuttles between the nucleus and cytoplasm, and can undergo post-translational modifications, 
such as phosphorylation (18, Di Liegro et al, unpublished obserations) and sumoylation (19), in response to extracellular stimuli.

\section{Materials and methods}

Animals. Sprague-Dawley rats (Stefano Morini, San Polo d'Enza, Italy) were housed under direction of a licensed veterinary, who also approved the experimental protocols. Procedures involving animals were conducted according to European Community Council Directive 86/609, OJL 5358 1, December 12, 1987.

Cell cultures and arsenic treatment. Astrocytes were prepared from two-day old newborn rats, as previously described (20), and cultured in DME/Hams F-12 (2/1), supplemented with $10 \%$ heat-inactivated fetal calf serum (Sigma-Aldrich, MO, USA), until half confluent.

For checking culture purity, astrocytes were cultured on coverslips, fixed with $96 \%$ ethanol on ice for $10 \mathrm{~min}$ and permeabilized for 5 min with $0.1 \%$ Triton X-100 in PBS. Cells were finally incubated with polyclonal rabbit anti-glial fibrillary acidic protein (GFAP) antibodies (Sigma-Aldrich).

Astrocyte cultures were treated with $\mathrm{NaAsO}_{2}$ (SigmaAldrich), at final concentrations of $2.5,5,10,30$, or $60 \mu \mathrm{M}$ in complete medium, for $24 \mathrm{~h}$. Arsenite was freshly dissolved in sterile double distilled water.

Acridine orange (AO)/ethidium bromide (EB) assay. Cell death was evaluated by staining astrocytes with $\mathrm{AO} / \mathrm{EB}$ mixture, each at a concentration of $100 \mu \mathrm{g} / \mathrm{ml}$ in PBS, as previously described (21). Cells were observed by an Olympus BX-50 fluorescent microscope (Olympus Italia SRL, Segrate, Italy).

Trypan blue exclusion test. Treated and untreated cells were stained for 5 min with $0.4 \%$ Trypan blue (Sigma-Aldrich), and counted using a Burker chamber under a light microscope with a x20 magnification. The Trypan blue dye is normally taken up by non-viable cells but not by viable cells because it only penetrates through damaged cellular membranes. Cell viability was expressed as the percentage of viable cells compared to the total number of counted cells. Three independent experiments were performed and data are reported as means \pm SD.

Alkaline comet assay. Comet assay was performed according to Andreoli (22) with some modifications. Briefly, exponentially growing cells were trypsinized and cell suspension, containing $1 \times 10^{6}$ cells, was plated in $100-\mathrm{mm}$ petri dishes. After $24 \mathrm{~h}$, cells were treated with increasing doses of $\mathrm{NaAsO}_{2}$ for $24 \mathrm{~h}$, and washed twice with Hank's salt solution. Cells collected by trypsinization were centrifugated at $800 \mathrm{rpm}$ for $10 \mathrm{~min}$, resuspended in PBS $\left(2 \times 10^{5}\right.$ cells $/ 10 \mathrm{ml}$ final concentration) and mixed with $65 \mu \mathrm{l}$ of $0.7 \%$ Low Melting Agarose (LMA, Bio-Rad). They were then layered on a slide (GelBond film, Sigma), previously coated with a layer of $0.5 \%$ Normal Melting Agarose (NMA, Fisher Molecular Biology), and covered with another layer of LMA. The agarose suspension was covered with a coverslip and placed at $4^{\circ} \mathrm{C}$ for $10 \mathrm{~min}$. The coverslip was gently removed and the slide was submerged into lysing solution (2.5 M NaCl, $100 \mathrm{mM} \mathrm{Na} 2$ EDTA, $10 \mathrm{mM}$ Tris, $10 \%$
DMSO, $1 \%$ Triton $\mathrm{X}-100, \mathrm{pH} 10.0$ ) for $1 \mathrm{~h}$ in the dark at $4^{\circ} \mathrm{C}$. After lysis, the slides were placed for $15 \mathrm{~min}$ in a horizontal electrophoresis gel tray containing fresh alkaline buffer (300 mM NaOH, $1 \mathrm{mM} \mathrm{Na} \mathrm{EDTA}_{2} \mathrm{pH}>8$ ) and then subjected to an electric field of $0.7 \mathrm{~V} / \mathrm{cm}$ in the dark at $4^{\circ} \mathrm{C}$ for $20 \mathrm{~min}$. Following electrophoresis the microgels were neutralized in $0.4 \mathrm{M}$ Tris- $\mathrm{HCl}$ ( $\mathrm{pH} 7.5)$, dehydrated in methanol for $2 \mathrm{~min}$ and allowed to dry at room temperature. The DNA was stained with ethidium bromide $(2 \mu \mathrm{g} / \mathrm{ml})$ (Electran BDH), and visually examined by fluorescence microscope (Nikon MicrophotFXA/SA), equipped with an HBO 100 mercury lamp and a suitable filter. Photomicrographs were processed using Photoshop 6.0 software (Adobe). For qualitative evaluation, at least 1,000 cells were scored for each dose. Cells were classified as undamaged, damaged with comet shape and ghosts with small head and large tails. DNA damage was quantified by tail length values (Ltail, $\mathrm{mm}$ ) calculated by CASP (Comet Assay Software Project).

Data derived from three independent experiments, with at least 50 cells per experiment (from two replicate slides each), were processed with the Kruskal-Wallis non-parametric statistical method.

ROS detection. Oxidative stress was evaluated using 5-(and6)-chloromethyl-2'7'-dichloro dihydrofluorescein diacetate acetyl ester (CM-H $\mathrm{H}_{2}$ DCFDA, Molecular Probes, Invitrogen). This probe becomes fluorescent when oxidation occurs within the cell.

Experiments were carried out according to the manufacturer's protocol. Briefly, $3 \times 10^{6}$ exponentially growing astrocytes, immediately after the arsenite treatment, were washed twice with Hank's salt solution, collected by trypsinization and then incubated in the dark with $25 \mu \mathrm{M}$ CM- $\mathrm{H}_{2}$ DCFDA for $1 \mathrm{~h}$. Finally, they were analysed by flow cytometer (FACScan Becton Dickinson), using excitation sources and filters appropriate for fluorescein (FITC). Treated and untreated cells were evaluated. As positive control, cells were treated for $1 \mathrm{~h}$ with $100 \mu \mathrm{M}$ tert-butyl hydroperoxide (TBHP). Experiments were repeated three times.

Western blot analysis. After treatment, astrocytes were collected, washed with PBS, and homogenized in homogenization buffer ( $0.32 \mathrm{M}$ sucrose; $50 \mathrm{mM}$ sodium phosphate buffer, $\mathrm{pH}$ 6.5; $50 \mathrm{mM} \mathrm{KCl} ; 0.5 \mathrm{mM}$ spermine; $0.15 \mathrm{mM}$ spermidine; $2 \mathrm{mM}$ EDTA, and $0.15 \mathrm{mM}$ EGTA), containing the protease inhibitors aprotinin $(2 \mu \mathrm{g} / \mathrm{ml})$, antipain $(2 \mu \mathrm{g} / \mathrm{ml})$, leupeptin $(2 \mu \mathrm{g} / \mathrm{ml})$, pepstatin A $(2 \mu \mathrm{g} / \mathrm{ml})$, benzamidine (1.0 mM), and phenylmethylsulfonyl fluoride $(1.0 \mathrm{mM})$, all purchased from Sigma-Aldrich. Total protein concentration was determined by the Ouant-i ${ }^{\mathrm{TM}}$ Protein Assay using a Qubit $^{\mathrm{TM}}$ fluorometer (Invitrogen). Equal amounts of proteins (10-20 $\mu \mathrm{g})$ were loaded onto each lane of $15 \%$ acrylamideSDS denaturing gels. After electrophoretic separation, samples were electroblotted onto a PVDF membrane $(0.45 \mu \mathrm{m}$ poresize, Amersham Biosciences). Concentrations of the samples on the membrane were visualized by staining with Ponceau Red for 5 min. Finally, the membrane was immunostained with one of the following antibodies: i) rabbit polyclonal antiHsp70 (Calbiochem, Darmstadt, Germany); ii) mouse polyclonal anti-Hsc70 (Santa Cruz, CA, USA); iii) rabbit 
0
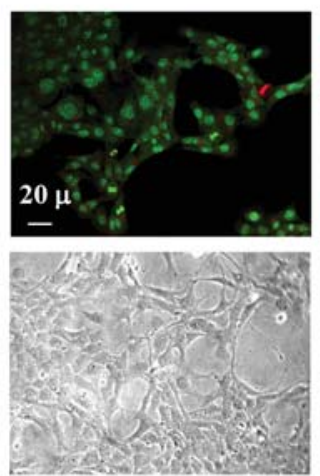

$5 \mu \mathbf{M}$
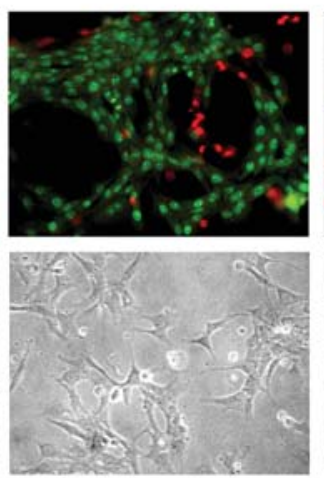

$10 \mu \mathrm{M}$
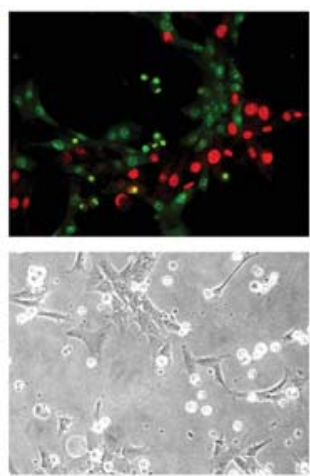

$30 \mu \mathrm{M}$
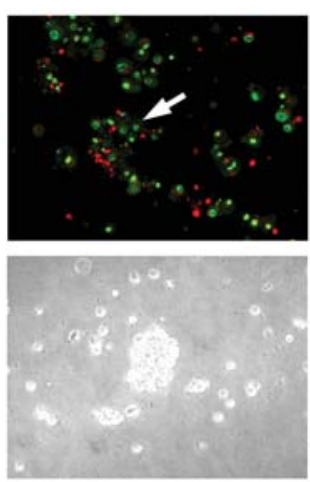

$60 \mu \mathrm{M}$


Figure 1. Astrocytes stained with a combination of the fluorescent DNA-binding dyes acridine orange and ethidium bromide. (a) Fluorescent microscopy; (b) light inverted microscopy. Cells were treated with 0,5,10,30 and $60 \mu \mathrm{M}$ arsenite. Cell cultures were prepared as described in Materials and methods, and treated with arsenite for $24 \mathrm{~h}$. Bar, $20 \mu$. Arrows indicate putative apoptotic bodies.

Table I. Trypan blue exclusion test after $24 \mathrm{~h}$ of sodium arsenite treatment

\begin{tabular}{cc}
\hline Arsenite concentration $(\mu \mathrm{M})$ & Viable cells $(\%)$ \\
\hline 0.0 & $99.0 \pm 3.9$ \\
2.5 & $90.0 \pm 7.0$ \\
5.0 & $91.9 \pm 5.9$ \\
10.0 & $86.4 \pm 12.0^{*}$ \\
30.0 & $77.5 \pm 8.3^{*}$ \\
60.0 & $63.2 \pm 7.8^{* *}$ \\
\hline
\end{tabular}

Data are the mean of three independent experiments $\pm \mathrm{SD} ;{ }^{*} \mathrm{P}<0.04$ vs control; ${ }^{* *} \mathrm{P}<0.01$ vs control, according to the Student's t-test.

polyclonal anti-PIPPin antibody, obtained in our laboratory, by immunizing rabbits with recombinant PIPPin, as already described (18); iv) rabbit polyclonal anti-superoxide dismutase 1 (Abcam, Cambridge, UK); v) rabbit polyclonal anti-superoxide dismutase 2 (Abcam). The secondary, antirabbit or anti-mouse antibodies were from Promega Corporation (WI, USA). In order to normalize the signals in identical conditions, in most experiments, the membranes were cut into two or even three horizontal stripes, each of which was immunostained with a different antibody. The intensity of bands was evaluated by the ImageJ programme. The measurements obtained from at least 4 independent experiments were finally used to calculate the relative concentrations of the analyzed proteins in the different conditions, as well as standard deviations (SD) and significance of the findings.

\section{Results}

Cell viability. For checking culture purity, astrocytes were cultured on coverslips and immunostained as described in Materials and methods. Typically $\geq 95 \%$ of cells were GFAPpositive (data not shown). Light microscopy of cells treated with increasing concentrations of sodium arsenite for $24 \mathrm{~h}$ indicated that cells started detaching from lower concentrations of arsenite ( 5 and $10 \mathrm{mM}$ ) and after exposure to 30 and $60 \mathrm{mM}$
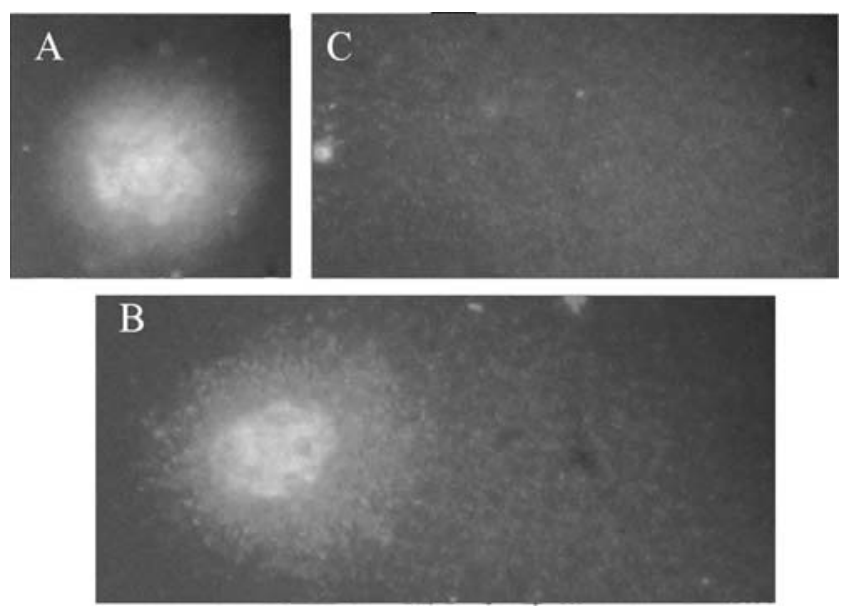

Figure 2. Representative photomicrographs of undamaged (A), damaged (B) and ghost rat astrocytes $(\mathrm{C})$, respectively, after comet assay. Nuclei were stained with ethidium bromide and observed using a fluorescence microscope at $\times 100$ magnification.

arsenite, only $\sim 15 \%$ of cells remained attached (Fig. 1b). Also attached cells appeared as increasingly damaged with respect to controls. As shown in Fig. 1a, staining of cells with a mixture of $\mathrm{AO}$ and $\mathrm{EB}$ demonstrated that the average number of viable (green) cells decreased, indeed, from $94 \pm 14$ (controls) to $83 \pm 10$ and $69 \pm 25 \%$, after treatment with 5 and $10 \mathrm{mM}$ arsenite, respectively. In cell cultures treated with 30 and $60 \mu \mathrm{M}$ of arsenite, the toxic effects were very severe and prevented the cell viability evaluation. However, it was possible to see some apoptotic cells (yellow).

Trypan blue exclusion test. As reported in Table I, exposure to $60 \mu \mathrm{M}$ arsenite resulted in $<70 \%$ relative viability with respect to control. Thus, this concentration was discarded for the evaluation of DNA damage by comet assay that requires the use of viable cells (23).

Comet assay. To evaluate DNA damage induced in primary cultures of rat astrocytes by exposure to arsenite, we used the comet assay. Preliminary qualitative analyses, performed by classifying cells in three groups, undamaged, damaged and 
Table II. Comet assay after $24 \mathrm{~h}$ of sodium arsenite treatment.

\begin{tabular}{lccc}
\hline $\begin{array}{l}\text { Arsenite concentration } \\
(\mu \mathrm{M})\end{array}$ & $\begin{array}{c}\text { Undamaged } \\
(\%)\end{array}$ & $\begin{array}{c}\text { Damaged } \\
(\%)\end{array}$ & $\begin{array}{c}\text { Ghost } \\
(\%)\end{array}$ \\
\hline 0 & $85.1 \pm 9.5$ & $14.1 \pm 10.1$ & $0.7 \pm 0.6$ \\
2.5 & $55.2 \pm 19.5$ & $42.5 \pm 21.1$ & $2.2 \pm 0.4$ \\
5.0 & $53.7 \pm 29.0$ & $39.6 \pm 24.1$ & $6.5 \pm 5.1$ \\
10 & $33.4 \pm 0.2$ & $43.1 \pm 0.7^{*}$ & $23.5 \pm 0.9^{* *}$ \\
30 & 0 & 0 & 100 \\
\hline
\end{tabular}

Data are the mean of three independent experiments $+\mathrm{SD} ;{ }^{*} \mathrm{P}<0.05$ vs control; ${ }^{* *} \mathrm{P}<<0.01$ vs control, according to the Student's t-test.

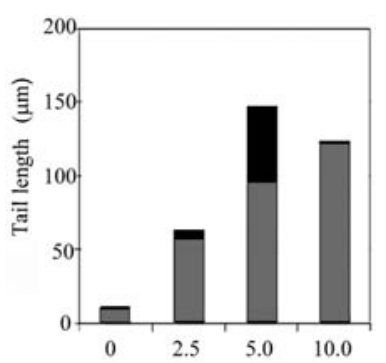

Figure 3. Comet assay, effect of $24 \mathrm{~h}$ treatment with $0,2.5,5$, and $10 \mu \mathrm{M}$ arsenite on DNA tail length. Grey bars represent the mean of three independent experiments. Black bars are SD. $\mathrm{p}<0.0001$, for all arsenite doses vs. control, according to Kruskal-Wallis test.

ghost cells (Fig. 2), revealed a significant dose-dependent increase of damaged and ghost cells (Table II). Quantitative evaluation, performed by CASP in cells exposed to 2.5, 5.0 and $10.0 \mu \mathrm{M}$, revealed a significant increase of the tail length in comparison with untreated cells (Fig. 3).

ROS detection. We assessed ROS levels in arsenite-treated astrocytes by measuring with flow cytometry their ability to oxidize the fluorogenic dye $\mathrm{CM}-\mathrm{H}_{2}$ DCFDA. The effect of arsenite treatment on the FACS histograms was not significant. However, at the highest doses of arsenite, a trend to a leftward shift was noted, indicating a lower degree of dye oxidation. For example, $10 \mu \mathrm{M}$ arsenite resulted in $35.54 \%$ decrease in fluorescence (Fig. 4). On the other hand, histograms of astrocytes treated with $100 \mu \mathrm{M}$ TBHP (positive control) show a clear rightward shift, indicating a greater oxidation of the dye.

Western blot analyses. We then analyzed the expression of stress proteins in astrocytes treated with increasing amounts of arsenite. As shown in Fig. 5, cells treated with 30-60 $\mu \mathrm{M}$ arsenite (i.e. cells which lost their normal morphology, Fig. 1), express high levels of the stress protein Hsp70, whereas they do not show any change in Hsp70 levels at lower arsenite concentrations. On the other hand, cells do not undergo any change in the housekeeping Hsc70 levels, at any arsenite concentration. We also studied the effect of arsenite on the expression of superoxide dismutases 1 and 2 (SOD1 and SOD2). As shown in Fig. 6, a slight, arsenite concentrationdependent, increase of SOD1 is evident up to $10 \mu \mathrm{M}$ arsenite (i.e. when cells still maintain normal morphology even if signs of cell damage are already evident, Fig. 1), while a decrease

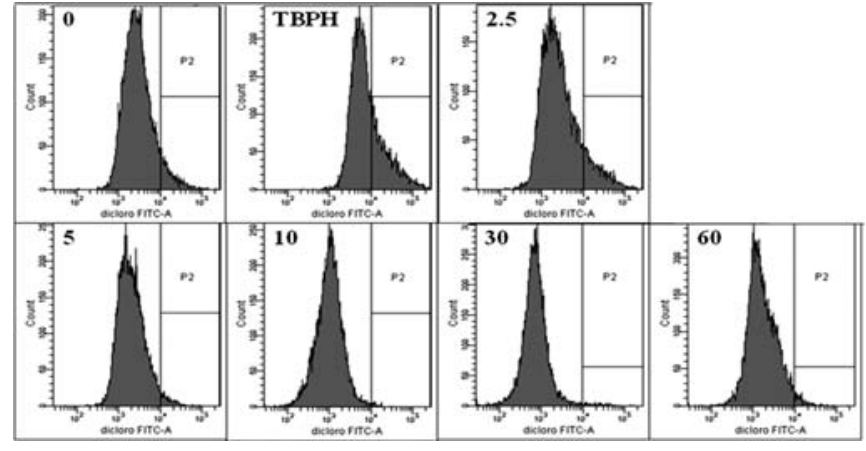

Figure 4. Fluorescence-activated cell sorting (FACS) histograms show the effects on astrocytes after treatment with different doses of arsenite $(0,2.5,5$, 10,30 and $60 \mu \mathrm{M}$ ) for $24 \mathrm{~h}$. Oxidative stress was evaluated using CM$\mathrm{H}_{2}$ DCFDA. As a positive control, astrocytes were also treated with $100 \mu \mathrm{M}$ TBHP. The histograms shown are representative of three independent experiments.
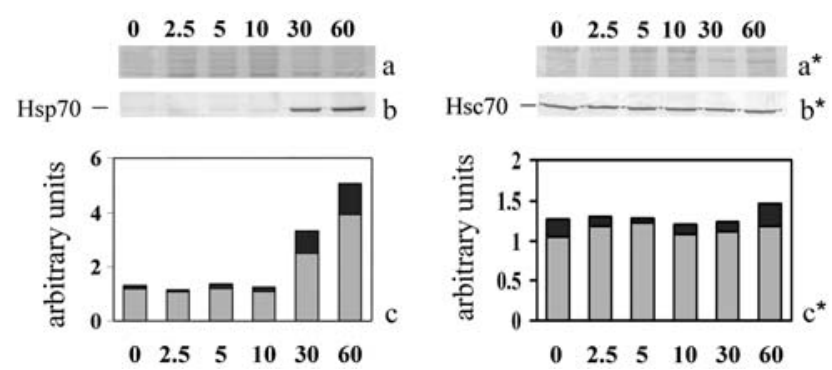

Figure 5. Western analysis of total cell proteins from astrocytes, treated with $0,2.5,5,10,30$, or $60 \mu \mathrm{M}$ arsenite, for $24 \mathrm{~h}$. Total proteins from cell lysates were immunostained with rabbit polyclonal anti-Hsp70 (Calbiochem, Darmstadt, Germany) antibodies (b), or mouse polyclonal anti-Hsc70 (Santa Cruz, CA, USA) antibodies ( $\left.b^{*}\right)$. Ponceau red-stained regions of the same membranes used for the Western blot analyses are shown in a, and $\mathrm{a}^{*}$, respectively. At least three independent Western blots were scanned and analyzed with the ImageJ program. The results were used to calculate mean relative concentrations of the proteins of interest (c, and $\left.c^{*}\right)$. Grey and black bars in $\mathrm{c}$ and $\mathrm{c}^{*}$ indicate mean values and $\mathrm{SD}$, respectively.

was observed at higher arsenite concentrations. No significant change of SOD2 was noted at any arsenite concentrations.

Finally, we analyzed the expression levels of RNA-binding protein PIPPin. As shown in Fig. 7, the expected main band of $\sim 30 \mathrm{kDa}$ increased at intermediate doses $(5 \mu \mathrm{M})$ of arsenite and decreased at the highest doses $(30$ and $60 \mu \mathrm{M})$ while, in parallel, a faster migrating band appeared of $\sim 28 \mathrm{kDa}$. 
$\begin{array}{llllll}0 & 2.5 & 5 & 10 & 30 & 60\end{array}$
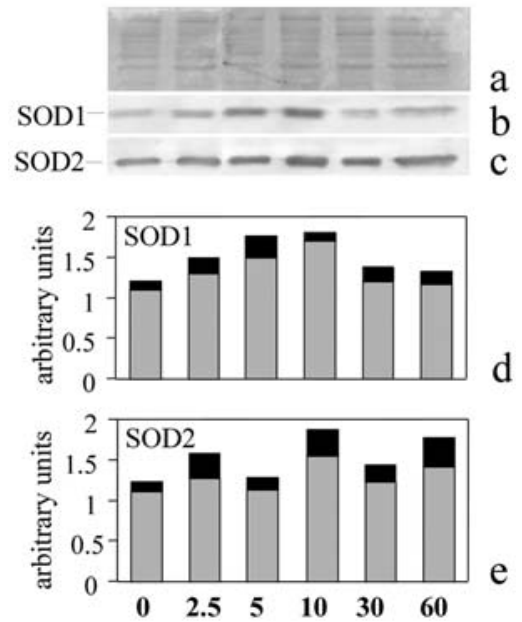

Figure 6. Western analysis of total cell proteins from astrocytes, treated with $0,2.5,5,10,30$, or $60 \mu \mathrm{M}$ arsenite, for $24 \mathrm{~h}$. Total proteins from cell lysates were immunostained with rabbit polyclonal anti-SOD1 (b) or anti-SOD2 (c) antibodies. A Ponceau red-stained region of the same membrane, used for Western blot analyses, is shown in a. At least three independent Western blots were scanned and analyzed with the ImageJ program. The results were used to calculate mean relative concentrations of the proteins of interest ( $\mathrm{d}$ and $\mathrm{e}$, respectively). Grey and black bars indicate mean values and SD, respectively.

\section{Discussion}

Chronic exposure to arsenic at nonlethal levels can result in a variety of outcomes including cognitive impairment (1). Neurotoxic effects have been reported both in clinical cases and animal experiments. It has been demonstrated that arsenic induces decreased locomotor activity and behavioral disorders in exposed male rats (15), and that the effects can be transmitted from the maternal to fetal tissues across the transplacental barrier (14).

Astrocytes, the most abundant glial cell population in the central nervous system (CNS), contribute to the establishment of the blood-brain barrier (24, and references therein), and perform functions particularly important in maintaining neuronal viability (25). Moreover, astrocytes form the front line in the brain parenchyma against foreign molecules crossing the blood-brain barrier. However, information on the putative ability of astrocytes in protecting neurons from arsenite toxicity is still scarce. Understanding the biochemical mechanisms of astrocyte response to the metalloid is thus of crucial importance for gaining further insights into the effects arsenic has on CNS.

In the present study, the exposure to micromolar concentrations of arsenite induced in primary cultured rat astrocytes both morphological and biochemical changes. As indicated by $\mathrm{AO} / \mathrm{EB}$ tests, most cells died at the highest doses of arsenite (30-60 $\mu \mathrm{M})$, and $20-30 \%$ of cells already underwent damage at lower arsenite concentrations $(5-10 \mu \mathrm{M})$. The percentage of suffering cells, however, is clearly higher, as demonstrated by directly looking at DNA damage by the comet assay (only $\sim 33 \%$ of cells still undamaged at $10 \mu \mathrm{M}$ arsenite). On the basis of these findings we should have expected an increase of ROS production in treated astrocytes, since on one hand, arsenic is known to induce modifications of ROS levels in other cell types (26), and, on the other,
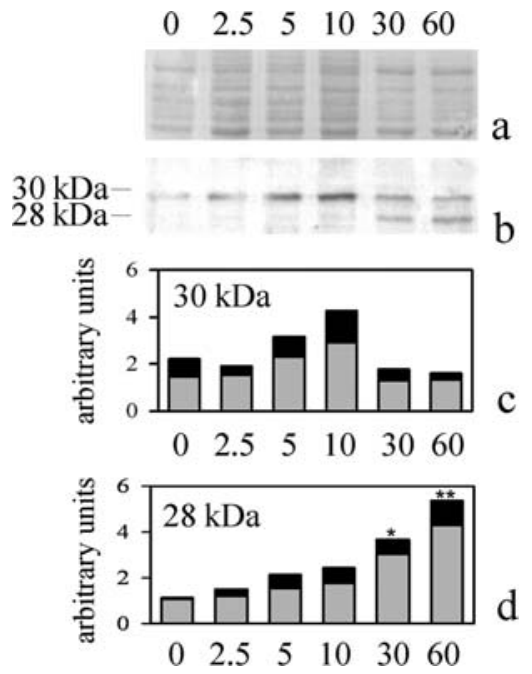

Figure 7. Western blot analysis of total cell proteins from astrocytes, treated with $0,2.5,5,10,30$, or $60 \mu \mathrm{M}$ arsenite, for $24 \mathrm{~h}$. Proteins were immunostained with rabbit polyclonal anti-PIPPin antibodies (b). A Ponceau red-stained region of the same membrane used for Western blot analysis is shown in a. At least three independent Western blots were scanned and analyzed with the ImageJ program. The results were used to calculate mean relative concentrations of both 30 - and $28-\mathrm{kDa}$ proteins (c and d, respectively). Grey and black bars indicate mean values and SD, respectively. ${ }^{*} \mathrm{p}<0.025$ vs control, and ${ }^{* *} \mathrm{p}<0.01$ vs control, respectively, according to the Student's t-test.

astrocytes are known to respond to certain stress with an increase of ROS production $(25,27)$. However, arsenite treatment did not induce increased ROS levels in astrocytes, but on the contrary a decrease, suggesting the occurrence of some modifications which result in a generally decreased rate of basal metabolism. A parallel slight increase of expression of SOD1 was found while cells were still resistant to the treatment (up to $10 \mu \mathrm{M}$ arsenite). On the other hand, even SOD1 decreased when cells are definitively damaged. Curiously, the mitochondrial SOD2 did not undergo any significant changes.

In the absence of ROS production, it is possible that the DNA damage evidenced by the comet assay is instead due to the production of trivalent methylated arsenic metabolites, which have been reported to be more toxic than arsenite both in vitro and in vivo, and capable of inducing DNA alkalilabile sites (26).

The only clear modification in the levels of proteins linked to stress was the highly significant increase of Hsp70, at the highest doses of arsenite (30 and $60 \mu \mathrm{M})$. This finding suggests that astrocytes sense arsenite exposure as a stress only at very high doses, when most cells are already too damaged to survive. It is probable that cells expressing Hsp70 are still alive even at the highest doses of arsenite.

Since other authors reported that the effects of arsenite could relate to modulations of $\mathrm{Ca}^{2+}$-induced signaling $(11,12)$, we also analyzed the effects of arsenite treatment on PIPPin, a putative RNA-binding protein (also known as CSD-C2), the concentration of which was recently found to decrease when neurons undergo a cadmium-induced stress (28). PIPPin is most closely related to CRHSP24, a protein particularly abundant in the pancreas, testis, liver, and lung, which has been suggested to be involved in calcium-mediated signal transduction $(29,30)$. First, we explored if PIPPin is also expressed 
in primary cultures of astrocytes and found that it is, even at lower levels with respect to neurons (data not shown). Second, we looked for modifications of its levels after arsenite treatment. Such as in the case of cadmium-induced stress (28), PIPPin concentration changes only at the highest doses of arsenite. In arsenite-treated astrocytes, however, we found a dose-dependent increase of a faster migrating protein, also stained by anti-PIPPin antibodies. The origin of this protein is still under analysis, but we hypothesize that it derives from a proteolytic event connected with stress-induced cell death.

In conclusion: i) arsenite exposure causes damage to astrocytes by a process not involving oxidative stress; ii) astrocytes appear to have a very high threshold for induction of stress proteins, such as Hsp70, a well known marker of cell stress, that does not increase until cells are exposed to very high concentrations of arsenite; iii) astrocytes express PIPPin; iv) arsenite exposure induces in rat astrocytes the production of a novel form of PIPPin, the analysis of which could shed further light on PIPPin involvement in stress response.

\section{Acknowledgements}

This work was entirely supported by the University of Palermo (Fondi di Ateneo, Università degli Studi di Palermo). I. Catanzaro and G. Schiera were supported by postdoctoral fellowships by Università degli Studi di Palermo, Palermo, Italy .

\section{References}

1. Kapaj S, Peterson H, Liber K and Bhattacharya P: Human health effects from chronic arsenic poisoning - a review. J Environ Sci Health A Tox Hazard Subst Environ Eng 41: 2399-2428, 2006.

2. Singh N, Kumar D and Sahu AP: Arsenic in the environment: effects on human health and possible prevention. J Environ Biol 28: 359-365, 2007.

3. IARC (International Agency for Research on Cancer): IARC Monographs on the Evaluation of the Carcinogenic Risk of Chemicals to Humans 23: Some Metals and Metallic Compounds. World Health Organization, Lyon, 1980.

4. Kitchin KT: Recent advances in arsenic carcinogenesis: modes of action, animal model systems, and methylated arsenic metabolites. Toxicol Appl Pharmacol 172: 249-261, 2001.

5. Chen Y, Parvez F, Gamble M, Islam T, Ahmed A, Argos M, Graziano JH and Ahsan H: Arsenic exposure at low-to-moderate levels and skin lesions, arsenic metabolism, neurological functions, and biomarkers for respiratory and cardiovascular diseases: review of recent findings from the Health Effects of Arsenic Longitudinal Study [HEALS] in Bangladesh. Toxicol Appl Pharmacol 239: 184-192, 2009.

6. Sciandrello G, Caradonna F, Mauro M and Barbata G: Arsenicinduced DNA hypomethylation affects chromosomal instability in mammalian cells. Carcinogenesis 25: 413-417, 2004.

7. Klein CB, Leszczynska J, Hickey C and Rossman TG: Further evidence against a direct genotoxic mode of action for arsenicinduced cancer. Toxicol Appl Pharmacol 222: 289-297, 2007.

8. Haga $\mathrm{N}$, Fujita $\mathrm{N}$ and Tsuruo T: Involvement of mitochondrial aggregation in arsenic trioxide $\left[\mathrm{As}_{2} \mathrm{O}_{3}\right]$-induced apoptosis in human glioblastoma cells. Cancer Sci 96: 825-833, 2005.

9. Liu SX, Davidson MM, Tang X, Walker WF, Athar M, Ivanov V and Hei TK: Mitochondrial damage mediates genotoxicity of arsenic in mammalian cells. Cancer Res 65: 3236-3242, 2005.

10. Du Y, Wang K, Fang H, Li J, Xiao D, Zheng P, Chen Y, Fan H, Pan X, Zhao C, Zhang Q, Imbeaud S, Graudens E, Eveno E, Auffray C, Chen S, Chen Z and Zhang J: Coordination of intrinsic, extrinsic, and endoplasmic reticulum mediated apoptosis by imatinib mesylate combined with arsenic trioxide in chronic myeloid leukemia. Blood 107: 1582-1590, 2006.
11. Florea AM, Splettstoesser F and Büsselberg D: Mechanisms of arsenic trioxide $\left[\mathrm{As}_{2} \mathrm{O}_{3}\right]$ induced calcium signals and cellular death in two human SY-5Y neuroblastoma and 293 embryonic kidney [HEK] cells. Toxicol Appl Pharmacol 220: 292-301, 2007.

12. Zhang TC, Cao EH, Li JF, Ma W and Qin JF: Induction of apoptosis and inhibition of human gastric cancer MGC-803 cell growth by arsenic trioxide. Eur J Cancer 35: 1258-1263, 1999.

13. Rodríguez VM, Carrizales L, Jiménez-Capdeville ME, Dufour L and Giordano M: The effects of sodium arsenite exposure on behavioral parameters in the rat. Brain Res Bull 55: 301-308, 2001.

14. Chattopadhyay S, Bhaumik S and Nag-Chaudhury A: Arsenic induced changes in growth development and apoptosis in neonatal and adult brain cells in vivo and in tissue culture. Toxicol Lett 128: 73-84, 2002.

15. Rodriguez VM, Carrizales L and Mendoza MS: Effects of sodium arsenite exposure on development and behavior in the rat. Neurotoxicol Teratol 24: 743-750, 2002.

16. Ratnaike RN: Acute and chronic arsenic toxicity. Postgrad Med J 79: 391-396, 2003.

17. Castiglia D, Scaturro M, Nastasi T, Cestelli A and Di Liegro I: PIPPin, a putative RNA-binding protein specifically expressed in the rat brain. Biochem Biophys Res Commun 218: 390-394, 1996.

18. Nastasi T, Scaturro M, Bellafiore M, Raimondi L, Beccari S, Cestelli A and Di Liegro I: PIPPin is a brain-specific protein that contains a cold-shock domain and binds specifically to $\mathrm{H} 1^{\circ}$ and H3.3 mRNAs. J Biol Chem 274: 24087-24093, 1999.

19. Bono E, Compagno V, Proia P, Raimondi L, Schiera G, Favaloro V, Campo V, Donatelli M and Di Liegro I: Thyroid hormones induce sumoylation of the cold shock domaincontaining protein PIPPin in developing rat brain and in cultured neurons. Endocrinology 148: 252-257, 2007.

20. Proia P, Schiera G, Mineo M, Ingrassia AMR, Santoro G, Savettieri G and Di Liegro I: Astrocytes shed extracellular vesicles that contain fibroblast growth factor- 2 and vascular endothelial growth factor. Int J Mol Med 21: 63-67, 2008.

21. Schiera G, Proia P, Alberti C, Mineo M, Savettieri G and Di Liegro I: Neurons produce FGF2 and VEGF and secrete them at least in part by shedding extracellular vesicles. J Cell Mol Med 11: 1384-1394, 2007.

22. Andreoli C, Leopardi P and Crebelli R: Detection of DNA damage in human lymphocytes by alkaline single cell gel electrophoresis after exposure to benzene or benzene metabolites. Mutat Res 377: 95-104, 1997.

23. Tice RR, Agurell E, Anderson D, Burlinson B, Hartmann A, Kobayashi H, Miyamae Y, Rojas E, Ryu J-C and Sasaki YF: The single cell gel/Comet assay: guidelines for in vitro and in vivo genetic toxicology testing. Environ Mol Mutagen 35: 206-221, 2000 .

24. Schiera G, Sala S, Gallo A, Raffa MP, Pitarresi GL, Savettieri G and Di Liegro I: Permeability properties of a three-cell type in vitro model of blood-brain barrier. J Cell Mol Med 9: 373-379, 2005.

25. Wang C-C, Fang K-M, Yang C-S and Tzeng S-F: Reactive oxygen species-induced cell death of rat primary astrocytes through mitochondria-mediated mechanism. J Cell Biochem 107: 933-943, 2009.

26. Rossman TG: Mechanism of arsenic carcinogenesis: an integrated approach. Mutat Res 533: 37-65, 2003.

27. Yang C-S, Tzou B-C, Liu Y-P, Tsai M-J, Shyue S-K and Tzeng S-F: Inhibition of cadmium-induced oxidative injury in rat primary astrocytes by the addition of antioxidants and the reduction of intracellular calcium. J Cell Biochem 103: 825-834, 2008.

28. Gerspacher C, Scheuber U, Schiera G, Proia P, Gygax D and Di Liegro I: The effect of cadmium on brain cells in culture. Int J Mol Med 24: 311-318, 2009.

29. Groblewski GE, Yoshida M, Bragado MJ, Ernst SA, Leykan J and Williams JA: Purification and characterization of a novel physiological substrate for calcineurin in mammalian cells. J Biol Chem 273: 22738-22744, 1998.

30. Auld G, Campbell DG, Morrice N and Cohen P: Identification of calcium-regulated heat-stable protein of $24 \mathrm{kDa}$ [CRHSP24] as a physiological substrate for PKB and RSK using KESTREL. Biochem J 389: 775-783, 2005. 